\title{
Parents' primary and secondary child care time adjustment to market time: Evidence from Australian mothers and fathers
}

Huong Dinh and Maria Racionero

The increase in female labour force participation in recent decades has arguably contributed to improved outcomes for women, such as higher earnings, savings and retirement incomes. There are, however, concerns about the implications of this trend for children's development. The link between parental child care time and children's development has been extensively explored in the psychology and sociology literature, and also more recently in the economics literature (Del Boca et al. 2014). Time is a limited resource that parents need to allocate to work and child care, alongside other uses. While it has been extensively documented that employed parents spend less time with children than non-employed ones, there is less evidence on the nature and magnitude of the trade-offs between child care and market time. How much child care time do mothers and fathers sacrifice when they increase their market time? How do mothers and fathers adjust their child care time in response to an increase in their partner's market time? Does the trade-off differ for different types of child care time or according to the age of children? 
The developmental psychology literature suggests that not just the total child care time but the type of child care time matters for children's development (Shaw and Bell 1993). A relatively common categorisation, which is easily implemented with time use survey data, distinguishes primary from secondary child care time. Primary child care is defined as being engaged in child care tasks (e.g. playing, reading or talking with children) as the main activity. Secondary child care is defined as being engaged in child care tasks while doing other activities (e.g. cooking, entertaining or gardening), rather than child care being the main activity. Primary child care requires more effort from parents and is thought to be more productive, in terms of children's development, than secondary child care (Zick and Bryant 1996; Gutiérrez-Domènech 2010). It has been shown that parents spend more of their total time providing secondary child care than primary child care regardless of employment status (Allard and Janes 2008). There is, however, less conclusive evidence on the way parents adjust their primary and secondary child care time, and in particular whether they prioritise one over the other, when they increase work time. Understanding how these adjustments are made is relevant when assessing the implications of increased labour force participation.

Previous studies have explored the relationship between parental child care time and market time. In this article, 'market time' stands for time spent in market work, as in Hallberg and Klevmarken (2003). Among these studies, a few have focused on the implications for primary and secondary child care (Nock and Kingston 1988; Gutiérrez-Domènech 2010; Craig et al. 2014; Bryant and Zick 1996). The available evidence is mixed. In the US, Nock and Kingston (1988) found a negative but very small relationship between parents' work time and some primary child care and secondary child care activities, with the magnitude larger for secondary child care. Bryant and Zick (1996) found a negative effect of parents' own work time on primary child care but a positive effect on secondary child care. In Spain, Gutiérrez-Domènech (2010) found that working mothers and fathers reduce primary child care time more than secondary child care when they increase their own work time. In Australia, Craig et al. (2014) found that full-time employed parents spend less time for both primary and secondary child care than non-employed parents. However, they found no evidence of significant differences in child care time between part-time and full-time employed parents. The available evidence on the effect of partners' work time is even patchier. Nock and Kingston (1988) found no significant effect of partners' work hours on 
either mothers' or fathers' primary child care time. However, they found effects of partners' work time on secondary child care time that differ by parent gender: fathers increase, while mothers decrease, secondary child care time when their partners increase work time.

The lack of conclusive evidence on the effects of market time on child care time may stem from the little attention paid to the prevalence of 'zero values' in time use data, the correlation between market time and child care time, or the role of the age of youngest child. In time use surveys, which are conducted on particular days, activities that household members do, but which do not happen to fall on those days, will be recorded as 'zero' in the survey; zero values of time use are common for child care and work-related activities. Individuals choose market time and child care time simultaneously. The time use decisions are therefore interdependent, making it important to properly account for the correlation between the time uses. While the age of children can affect how much child care time parents are willing to trade off for market time, only Bryant and Zick (1996) conduct the analysis separately by the age of the youngest child in the family.

Our study accordingly focuses on the trade-off of primary and secondary child care time for market time for Australian parents. Specifically, we examine the following questions: (1) Do parents trade off less primary than secondary child care time for their own increased market time? (2) Do parents spend more extra time in primary than in secondary child care time when their partners increase their market time?

We study mothers and fathers separately to identify whether there are gender patterns in the way they trade off primary and secondary child care time for market time. In many developed countries, including Australia, and despite the observed increase in women's workforce participation, fathers spend more time in paid work and less time in child care than mothers. Many mothers choose to reduce their hours at work, seek to access flexible working arrangements including self-employment, or work in lower status jobs or industries (Kaufman and Uhlenberg 2000; Sayer 2005; Craig and Sawrikar 2009). In Australia, both cross-sectional and longitudinal studies show that mothers choose to work part time in order to balance work and child care, an option less often taken by fathers (Charlesworth et al. 2011; Cooklin et al. 2016). 
We also conduct our analysis separately by the age of the youngest child to explore whether there are child age-specific differences in how parents trade off primary and secondary child care for market time. There is a growing body of evidence on the importance of parental time investments in children's early years (Furedi 2001; Nadesan 2002; Quirke 2006; Wall 2010). The amount of time spent with children is particularly large when children are young and tends to decrease when they grow (Craig and Sawrikar 2009).

We use time-diary data on couples with children from the Australian Bureau of Statistics (ABS) 2006 Australian Time Use Survey (TUS), which provides the most up-to-date snapshot on how Australian parents allocate their time. We address the existing gaps in the literature and find relatively clear-cut evidence on how the trade-offs of child care time for market time differ for mothers and fathers, for primary and secondary child care time, and according to the age of youngest child. Our approach also enables us to explore the adjustments to primary and secondary child care time mothers and fathers make in response to increased market time by partners. These findings should help inform the design of policies to foster female labour force participation that take into account the effects of increased market time on child care time. The rest of the chapter is structured as follows. In Section 2, we describe the data source, data sample, key variables and covariates and main aspects of the econometric model used in the analysis. In Section 3, we outline the analysis results. In Section 4, we discuss the results and conclude.

\section{Methodology}

\section{Data}

The ABS TUS that we use contains two consecutive days worth of timediary data on 6,902 people aged 15 and over in a random sample of 3,626 households. Respondents are asked to report detailed time use for main (primary) activities and any simultaneous (secondary) activities that they engage in-including who they are with and where they are throughout the day-with reference to over 226 defined activities, to a detail level of five-minute intervals. The survey also provides detailed information about personal characteristics such as education, employment status and earnings. More details on the TUS 2006 are available in ABS (2008). 


\section{Data selection}

For our research purposes, we restrict our sample to working mothers and fathers in couple households, either married or cohabiting, aged 24-65 years with at least one child aged $0-14$ (this is the range that the TUS collects child care data). This yields a sample of 544 working mothers and 700 working fathers.

\section{Key variables}

The key time variables are time in child care and market work. Following Craig et al. (2014), we classify parental child care time into primary and secondary. Primary child care time is the total sum of minutes during which a person reported being engaged in any of the following child care-related tasks as his or her primary activity: minding children, taking care of children, teaching/helping/reprimanding children, playing/ reading/talking with children, performing physical or emotional care of children, travelling in association with child care or with children, and miscellaneous child care that includes child care not further defined or not elsewhere classified. Secondary child care time is the total amount of time that each parent spent for all mentioned child care-related tasks as a secondary activity. Our measure of child care time explicitly excludes any time that the reporting individual spent sleeping and napping with the child. Their 'default care' time is counted only if they were awake while the child slept. Ideally, the time with children should be recorded for each individual child but, in reality, it is hard to do so, especially for families with multiple children. Therefore, we use the time each parent recorded spending with all children present in the family. Time in market work is the total sum of minutes that the reporting individual devoted to work (including overtime and work brought home), travel and communication associated with employment-related activities, and any other employment-related activities. We use the actual market work time recorded in the diary rather than the contracted market work time as the former is more responsive to daily changes for reasons such as own sickness or a child's care need (Hallberg and Klevmarken 2003), therefore more accurately capturing the trade-off between market time and parental child care time. 


\section{Covariates}

In exploring the relationship between child care and market time it is important to control for variables that may confound this association, known as covariates. The covariates that we include are person-level and household-level characteristics that are commonly used in time use studies (e.g. Hallberg and Klevmarken 2003; Kimmel and Connelly 2007; Craig et al. 2014). The person-level characteristics include age groups (25-34, 35-44 and 45-64), education level (completing Year 12 or higher versus Year 11 or lower), country of birth (Australian or primarily English-speaking country background versus otherwise), self-rated health (very good or excellent versus good, fair or poor), receiving non-labour income or not and the number of weekend days reported in the two-day diary. Household-level information includes number of children $(1,2-3$, 4 and more), and household income group. The descriptive summary of covariates is provided in Table 7.A1 in the Appendix.

\section{Econometric model}

Following recent studies (Kimmel and Connelly 2007; Connelly and Kimmel 2009), we jointly estimate Tobit models of the trade-offs between (primary and secondary) child care time and market time, allowing for all three dimensions of time to be correlated, and controlling for relevant covariates. We do this to account for the 48-hour constraint faced by each respondent, which causes time spent in one activity to reduce the time available for another activity. This estimation approach also allows us to take into account zero time uses reported in time diaries. Additionally, it allows us to control for unobserved personal-specific characteristics that affect the individual's time allocation. The detailed econometric model is available in Dinh and Racionero (2016).

\section{Results}

\section{Time use}

Figure 7.1 presents the average time mothers and fathers report they spend on child care and work in the two diary days. On average, mothers spend 888 minutes for child care: 31 per cent of their time budget, nearly double the amount of time that fathers spend ( 472 minutes). Despite this substantial difference, both parents spend a third of total child care time in primary child care (301 minutes for mothers and 151 minutes for fathers), 
and two-thirds in secondary child care $(588$ minutes for mothers and 321 minutes for fathers). Mothers devote 360 minutes to work (about 40 per cent of their child care time) in contrast to 733 minutes for fathers (about 155 per cent of their child care time). The stark gender differences in child care time and work time suggest that on average mothers prioritise child care time while fathers prioritise work time, which is consistent with the findings in a number of previous studies (e.g. Acock and Demo 1994; Casper and Bianchi 2001; Baxter 2002; Craig and Bittman 2005).

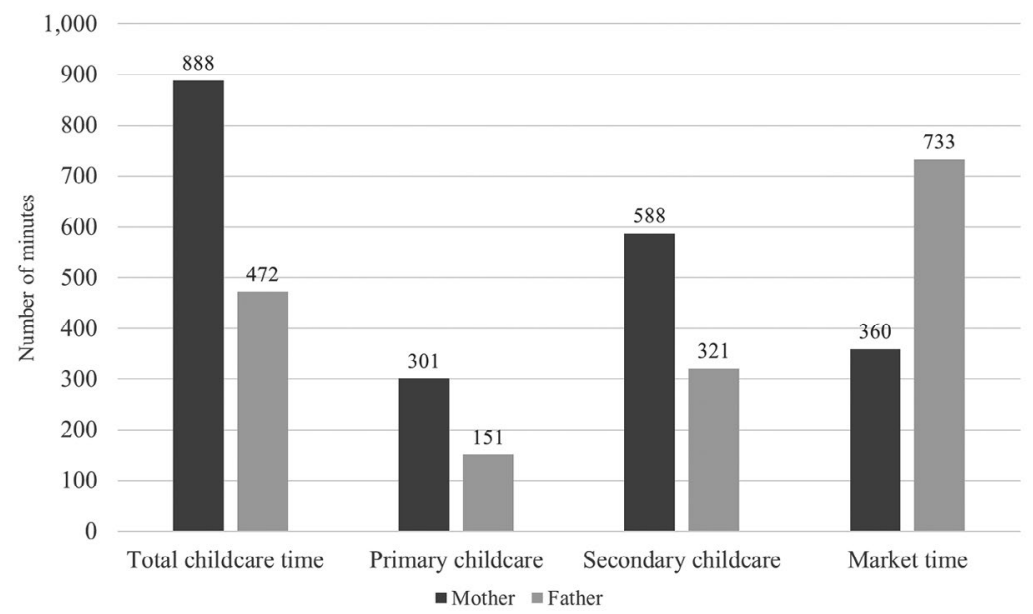

Figure 7.1: Unadjusted child care and market time by parent gender Source: Authors' estimation based on ABS TUS 2006.

We also explore whether the child care-work time pattern changes with the age of children. This is shown in Figures 7.2 and 7.3. Both mothers and fathers with a preschool-aged youngest child report more than double time in child care $(1,365$ minutes for mothers and 641 minutes for fathers) compared with those with a school-aged youngest child (565 minutes for mothers and 329 minutes for fathers). This pattern holds for both primary and secondary child care: for example, mothers with a preschool-aged youngest child spend 468 minutes in primary child care and 897 minutes in secondary child care, while mothers with a schoolaged youngest child spend 187 minutes in the former and 378 minutes in the latter. Both fathers and mothers spend more time in secondary child care than primary child care, regardless of the age of their youngest child, which is not surprising since primary child care requires more effort than secondary child care. The age of the youngest child seems to be a significant factor in the mother's decision of how much time to devote to work, but it does not seem to be the case for fathers. Mothers 
with a school-aged youngest child report 130 per cent of the amount of market time (400 minutes) compared with mothers with a preschoolaged youngest child (301 minutes). There is, however, no statistically significant difference for fathers, who devote 751 minutes to work when their youngest child is preschool-aged and 717 minutes when the youngest child is school-aged.

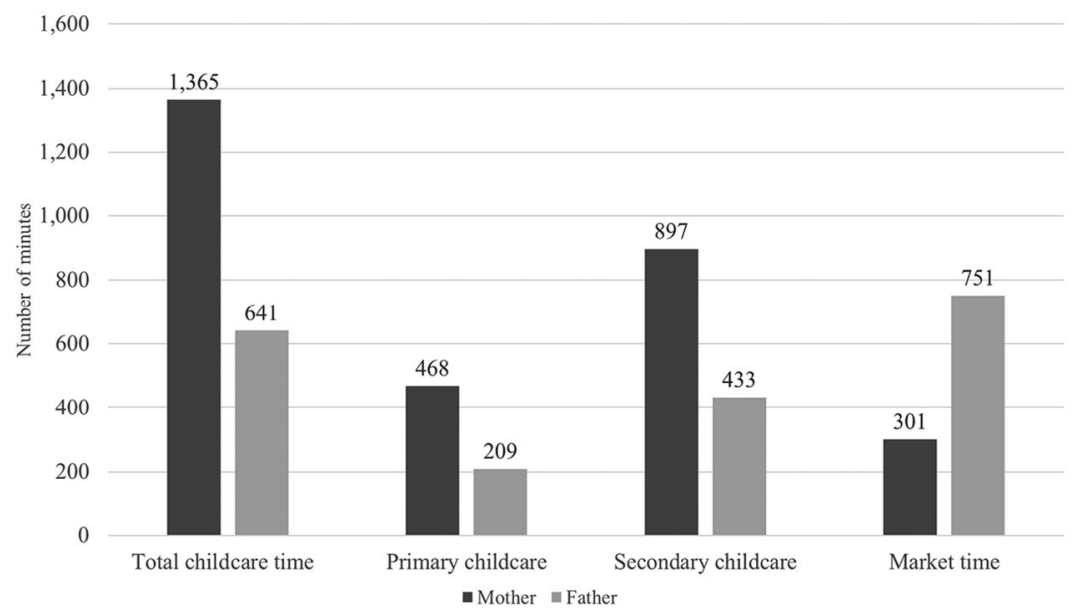

Figure 7.2: Unadjusted child care and market time by parent gender, youngest child at preschool age

Source: Authors' estimation based on ABS TUS 2006.

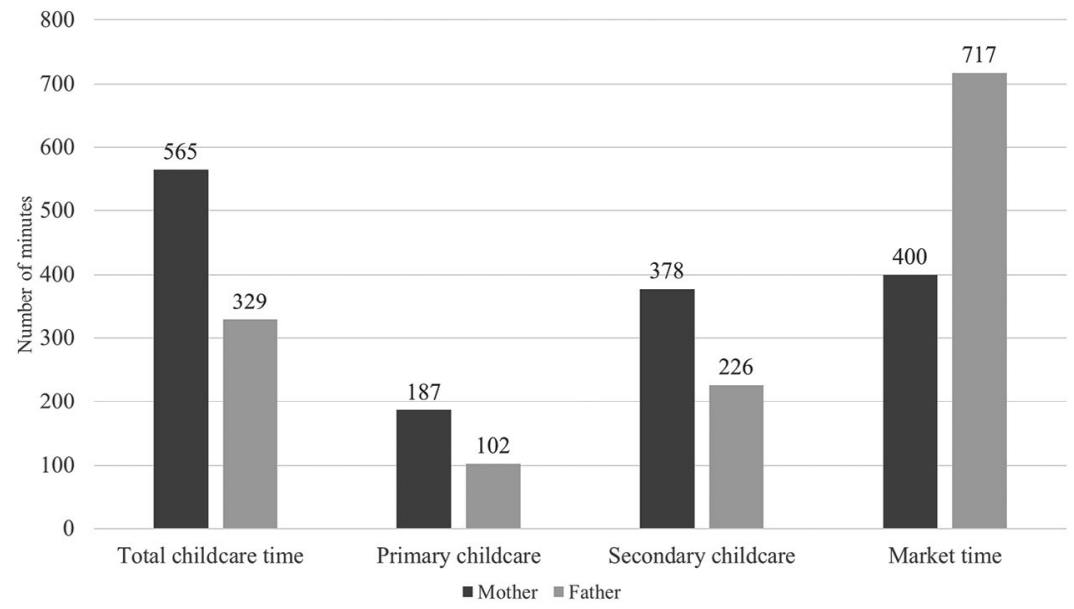

Figure 7.3: Unadjusted child care and market time by parent gender, youngest child at school age

Source: Authors' estimation based on ABS TUS 2006. 
The stylised facts identified above warrant more rigorous analysis. The average patterns suggest that there are differences in primary child care time, secondary child care time and market time use by fathers and mothers, and by age of youngest child. However, in order to understand the precise relationship, we need to control for relevant covariates (i.e. other variables that affect these time uses and may confound the observed relationship) and to properly account for the correlation between time uses. We do so in our analysis and report the results in terms of the marginal effect of parental market time on parental child care time, measured by a change in the amount of minutes in child care time associated with an additional minute devoted to market work.

Tables 7.1 and 7.2 present the marginal effects of own and partners' market time on the amount of time mothers and fathers spend in primary and secondary child care for preschool-aged and school-aged youngest child, respectively. For convenience, the impact is interpreted below in terms of the change in minutes in each type of child care for an extra hour of work. The full regression results are available in Dinh and Racionero (2016).

Table 7.1: Trade-offs between market time and child care time, youngest child (0-4 years), adjusted

\begin{tabular}{|l|c|c|c|c|c|c|c|c|}
\hline \multirow{2}{*}{} & \multicolumn{4}{|c|}{ Mother } & \multicolumn{4}{c|}{ Father } \\
\cline { 2 - 9 } & \multicolumn{2}{|c|}{$\begin{array}{c}\text { Primary child } \\
\text { care }\end{array}$} & \multicolumn{2}{c|}{$\begin{array}{c}\text { Secondary } \\
\text { child care }\end{array}$} & \multicolumn{2}{c|}{$\begin{array}{c}\text { Primary child } \\
\text { care }\end{array}$} & \multicolumn{2}{c|}{$\begin{array}{c}\text { Secondary } \\
\text { child care }\end{array}$} \\
\cline { 2 - 9 } & Coef. & SE & Coef. & SE & Coef. & SE & Coef. & SE \\
\hline Own market time & 0.13 & $(0.16)$ & $-0.84^{*}$ & $(0.50)$ & $-0.50^{\star \star \star}$ & $(0.12)$ & $0.85^{*}$ & $(0.48)$ \\
\hline $\begin{array}{l}\text { Partner's market } \\
\text { time }\end{array}$ & $0.11^{* \star \star}$ & $(0.03)$ & 0.04 & $(0.09)$ & $0.05^{\star}$ & $(0.03)$ & $0.22^{*}$ & $(0.13)$ \\
\hline
\end{tabular}

Robust standard errors in parentheses.

Significance level: *** $p<0.01,{ }^{* *} p<0.05,{ }^{*} p<0.1$.

Source: Authors' estimation based on ABS TUS 2006.

Table 7.2: Trade-offs between market time and child care time, youngest child (5-14 years), adjusted

\begin{tabular}{|l|c|c|c|c|c|c|c|c|}
\hline \multirow{2}{*}{} & \multicolumn{4}{|c|}{ Mother } & \multicolumn{4}{c|}{ Father } \\
\cline { 2 - 9 } & \multicolumn{2}{|c|}{$\begin{array}{c}\text { Primary child } \\
\text { care }\end{array}$} & \multicolumn{2}{c|}{$\begin{array}{c}\text { Secondary } \\
\text { child care }\end{array}$} & \multicolumn{2}{c|}{$\begin{array}{c}\text { Primary child } \\
\text { care }\end{array}$} & \multicolumn{2}{c|}{$\begin{array}{c}\text { Secondary } \\
\text { child care }\end{array}$} \\
\cline { 2 - 9 } & Coef. & SE & Coef. & SE & Coef. & SE & Coef. & SE \\
\hline Own market time & $-0.25^{\star \star \star}$ & $(0.08)$ & -0.28 & $(0.54)$ & $-0.29^{\star \star \star}$ & $(0.08)$ & $-1.38^{\star \star \star}$ & $(0.46)$ \\
\hline $\begin{array}{l}\text { Partner's market } \\
\text { time }\end{array}$ & $0.07^{\star \star \star}$ & $(0.02)$ & -0.07 & $(0.08)$ & $0.06^{\star \star \star}$ & $(0.02)$ & $0.33^{\star \star \star}$ & $(0.12)$ \\
\hline
\end{tabular}

Robust standard errors in parentheses.

Significance level: ${ }^{\star \star \star} p<0.01,{ }^{\star \star} p<0.05,{ }^{*} p<0.1$.

Source: Authors' estimation based on ABS TUS 2006. 


\section{Do parents trade off less primary than secondary child care time for their own increased market time?}

In families with a preschool-aged youngest child, mothers keep primary child care time unchanged but reduce secondary child care time by 50 minutes when they increase market time by one hour. By contrast, fathers reduce primary child care time by 30 minutes but increase secondary child care time by 51 minutes when they work an extra hour. In families with a school-aged youngest child, mothers reduce primary child care time by 15 minutes and there is no statistically significant change in secondary child care time when they increase market time by one hour. Fathers reduce both primary and secondary child care time, especially secondary child care by 84 minutes as opposed to 18 minutes in primary child care, when they work an extra hour.

The results indicate that parents' adjustments to primary and secondary child care time differ and depend on the parent gender and the age of the youngest child. When the youngest child is preschool-aged, mothers seem to prioritise primary child care over secondary child care: they keep primary child care time unchanged while reducing secondary child care time by a slightly lower amount than the increase in own market time. However, when the youngest child is school-aged, mothers seem to put more emphasis on secondary child care time: they maintain secondary child care time while reducing primary child care time, albeit at a lower rate than the increase in own market time. By contrast, when the youngest child is preschool-aged, fathers seem to prioritise secondary child care over primary child care; they increase secondary child care time but reduce primary child care time although at half the rate of the increase in own market time. When the youngest child is school-aged, fathers reduce time in both child care types but less so in primary child care than in secondary child care.

\section{Do parents spend more extra time in primary than in secondary child care time when their partners increase their market time?}

In families with a preschool-aged youngest child, mothers increase primary child care time by 7 minutes, but there is no evidence that they change secondary child care time when their partners' market time increases by one hour. Meanwhile, fathers increase primary child 
care time by 3 minutes and secondary child care time by 17 minutes when their partners' market time increases by one hour. In families with a school-aged youngest child, mothers increase primary child care time by 4 minutes with no evidence of changes in secondary child care time when their partners' market time increases by one hour. Fathers increase primary child care time by 4 minutes and secondary child care time by 23 minutes when their partners' market time increases by one hour.

The above results imply that the adjustments in child care time in response to an increase in partner's market time also depend on the type of child care time (primary or secondary), the parent gender and the age group of the youngest child. Regardless of the age of the youngest child, mothers seem to prioritise primary over secondary child care when their partners increase work time: mothers increase primary child care time and maintain secondary child care time. On the contrary, fathers seem to prioritise secondary child care compared with primary child care: regardless of the age of the youngest child, fathers increase both types of child care, but secondary child care significantly more than primary child care, in response to an increase in partner's work time.

\section{Conclusions}

Time is a scarce resource that parents need to allocate to work and child care, alongside other uses. In this study, we have explored the extent to which Australian mothers and fathers adjust their child care time in response to an increase in own and partner's market time. We focused on primary and secondary child care time. Primary child care is more interactive and is expected to have more productive effects on a child's development than secondary child care. While it had been previously documented that parents spend more of total child care time in secondary child care than primary child care, there was little conclusive evidence on how parents adjust their primary and secondary child care time, and in particular whether they prioritise one over the other, when they increase their work time. We have accordingly contributed to the literature by providing evidence on how mothers and fathers trade off both primary and secondary child care time for own and partner's increased market time. To do so, we used the most recent Australian TUS 2006. 
We find that mothers and fathers adjust their child care time differently depending on which partner (father or mother) increases market time, which child care type (primary and secondary) is considered and the age group their youngest child belongs to (less than 5 years or 5-14 years old).

In families with a preschool-aged youngest child, and in response to an increase in own market time, mothers keep primary child care time unchanged but reduce secondary child care time significantly. By contrast, fathers reduce primary child care time moderately and increase secondary child care time significantly when their own market time increases. They may accomplish this by combining their primary activity (e.g. entertaining, gardening, etc.) with child care or reducing other time uses. In families with a school-aged youngest child, mothers decrease primary child care time and maintain secondary child care time, while fathers decrease both primary and secondary child care time, although more so the latter, in response to an increase in their own market time. Fathers and mothers also respond differently to the increase in partner's market time: mothers maintain secondary child care time and increase primary child care time, more so when the youngest child is preschoolaged, while fathers increase both primary and secondary child care time, with the increase in secondary child care time being larger, and more so when the youngest child is school-aged.

There is hence a gender pattern in the adjustments made by parents to primary and secondary child care time in response to an increase in both own and partner's market time. For families with a preschool-aged youngest child, mothers seem to prioritise primary child care time whereas fathers seem to prioritise secondary child care time. This holds both for responses to increases in own and partner's market time. The different choices that mothers and fathers make regarding the types of child care they engage in can have real implications for children's development and wellbeing: primary child care, where child care activities are recorded as the primary activity parents engage in, is likely to be more conducive to children's development and wellbeing.

The gender patterns are less obvious in the case of families with a schoolaged youngest child. Both mothers and fathers decrease primary child care time, and fathers significantly decrease secondary child care time, in response to an increase in own market time. Both mothers and 
fathers increase primary child care time, and fathers significantly increase secondary child care time, in response to an increase in partner's market time.

Combining the parents' child care time adjustments to changes in own and partners' work time suggest that partners balance their child care time in order to minimise not only the loss in total child care time, but also the loss in each subcategory of primary and secondary child care time. In families with a preschool-aged youngest child, a reduction in mothers' secondary child care time due to her increased work time is partially outweighed by an increase in fathers' secondary child care time. Similarly, a reduction in fathers' primary child care time due to his increased work time is partially outweighed by an increase in mothers' primary child care time. In families with a school-aged youngest child, a reduction in mothers' primary and secondary child care time due to her increased work time is outweighed by an increase in fathers' primary and secondary child care time, largely so for secondary child care time. The decrease in fathers' primary and secondary child care time due to his increased work time is, however, associated with relatively small increases in mothers' primary child care time.

Our most compelling finding is that mothers prioritise primary child care, both in response to own or partner's increased market time, when the youngest child is preschool-aged. Their reluctance to trade off primary child care time suggests that they particularly value this type of productive but costly use of time. The mothers' avoidance of a one-for-one trade-off of primary child care for market time may mean that they allocate less time to other activities, including child care-free leisure, personal care and sleeping, that they reschedule activities from weekdays to weekends or to earlier in the day (Craig 2007) or that they increase the intensity of other activities in a reduced amount of time. Some of these adjustments are likely to negatively affect mothers' wellbeing.

More flexible work arrangements for both mothers and fathers, including flexible work schedules and work from home, could help couples, particularly those with young children, balance their child care time. Flexible work arrangements could mitigate existing problems of access to affordable, high-quality non-parental child care. Provision of high-quality non-parental child care, as discussed by Guyonne Kalb (Chapter 5, this volume) could also help relax the time constraints mothers face, particularly those with very young children, without compromising their health or their children's development. 
In this study, we have focused on primary and secondary child care time, which is a relatively standard categorisation that is easily implemented using most time-diary data sets. Kalenkoski and Foster (2008) argue, however, that there are alternative ways of capturing the quality dimension of parental time inputs to child production. They propose alternative high- and lowquality time definitions that may be worth exploring in further research.

\section{Appendix}

Table 7.A1: Descriptive summary

\begin{tabular}{|c|c|c|c|c|}
\hline & $\begin{array}{l}\text { Whole } \\
\text { sample }\end{array}$ & Mother & Father & t statistics ${ }^{a}$ \\
\hline Number of observations & 1,244 & 544 & 700 & \\
\hline \multicolumn{5}{|l|}{ Personal characteristics } \\
\hline \multicolumn{5}{|l|}{ Age group (\%) } \\
\hline$(25-34)$ & 23.1 & 26.5 & 20.5 & $2.4^{\star \star}$ \\
\hline$(35-44)$ & 55.6 & 59.3 & 52.7 & $2.3^{\star \star}$ \\
\hline 45 and more & 21.4 & 14.3 & 26.8 & $-5.4^{\star \star \star}$ \\
\hline \multicolumn{5}{|l|}{ Education (\%) } \\
\hline Tertiary qualification & 38.3 & 43.5 & 34.3 & $3.3^{\star \star \star}$ \\
\hline Certificate or Year 12 & 40.0 & 32.3 & 46.0 & $-4.9^{\star \star \star}$ \\
\hline Year 11 or below & 21.7 & 24.2 & 19.7 & $1.9^{*}$ \\
\hline Australian or main English speaking (\%) & 86.1 & 87.1 & 85.4 & 0.4 \\
\hline $\begin{array}{l}\text { English as the main home spoken } \\
\text { language (\%) }\end{array}$ & 92.7 & 92.9 & 92.7 & 0.2 \\
\hline \multicolumn{5}{|l|}{ General health (\%) } \\
\hline Very good or excellent & 30.2 & 27.4 & 32.4 & $-1.9^{*}$ \\
\hline Good, fair or poor & 62.7 & 66.4 & 59.8 & $2.4^{\star \star}$ \\
\hline Not stated & 7.1 & 6.2 & 7.8 & -1.1 \\
\hline $\begin{array}{l}\text { Has disability or long-term health } \\
\text { condition (\%) }\end{array}$ & 17.7 & 14.8 & 19.9 & $2.3^{\star \star}$ \\
\hline Professional (\%) & 37.3 & 34.0 & 39.9 & $2.14^{\star *}$ \\
\hline \multicolumn{5}{|l|}{ Number of minutes worked in two days (\%) } \\
\hline$<480$ & 46.3 & 65.5 & 31.6 & $12.5^{\star \star \star}$ \\
\hline $480-839$ & 19.2 & 17.8 & 20.3 & -1.1 \\
\hline 840-959 & 4.7 & 3.8 & 5.5 & -1.4 \\
\hline $960-1,199$ & 16.4 & 9.8 & 21.5 & $-5.6^{\star \star \star}$ \\
\hline
\end{tabular}


7. PARENTS' PRIMARY AND SECONDARY CHILD CARE TIME ADJUSTMENT TO MARKET TIME

\begin{tabular}{|c|c|c|c|c|}
\hline & $\begin{array}{l}\text { Whole } \\
\text { sample }\end{array}$ & Mother & Father & t statistics ${ }^{a}$ \\
\hline 1,200 or more & 13.4 & 3.2 & 21.2 & $-9.5^{\star \star \star}$ \\
\hline Work at weekend (\%) & 26.9 & 20.1 & 32.1 & $-4.8^{\star \star \star}$ \\
\hline Receiving non-labour income (\%) & 43.4 & 41.8 & 44.5 & -0.3 \\
\hline \multicolumn{5}{|l|}{ Household characteristics } \\
\hline \multicolumn{5}{|l|}{ Number of children (\%) } \\
\hline One & 36.6 & 37.9 & 35.6 & 0.8 \\
\hline Two & 46.2 & 46.7 & 45.8 & 0.3 \\
\hline Three or more & 17.2 & 15.4 & 18.6 & -1.5 \\
\hline \multicolumn{5}{|l|}{ Youngest child group (\%) } \\
\hline$(0-4)$ & 43.8 & 40.9 & 46.0 & $-1.8^{*}$ \\
\hline$(5-11)$ & 41.0 & 42.8 & 39.6 & 1.1 \\
\hline$(12-14)$ & 15.2 & 16.3 & 14.4 & 0.9 \\
\hline Family with a disable child (\%) & 14.8 & 35.5 & 13.7 & -0.3 \\
\hline Family with a disable person (\%) & 38.9 & 48.8 & 38.5 & 0.9 \\
\hline $\begin{array}{l}\text { Having more than one women in the } \\
\text { household (\%) }\end{array}$ & 10.8 & 31.0 & 11.8 & 1.1 \\
\hline \multicolumn{5}{|l|}{ Income quintile (\%) } \\
\hline Not stated & 9.8 & 9.4 & 10.1 & -0.4 \\
\hline Lowest & 5.9 & 5.3 & 6.3 & -0.8 \\
\hline 2 & 16.3 & 14.3 & 17.9 & $-1.7^{*}$ \\
\hline 3 & 25.6 & 25.7 & 25.5 & 0.1 \\
\hline 4 & 23.1 & 24.8 & 21.8 & 1.2 \\
\hline Highest & 19.4 & 20.6 & 18.4 & 1.0 \\
\hline \multicolumn{5}{|c|}{ Index of relative socioeconomic disadvantage (\%) } \\
\hline Lowest $20 \%$ - Most disadvantaged & 12.6 & 11.4 & 13.5 & -1.1 \\
\hline Second quintile & 22.0 & 22.3 & 21.8 & 0.2 \\
\hline Third quintile & 20.3 & 20.6 & 20.0 & 0.3 \\
\hline Highest quintile - Least disadvantaged & 45.1 & 45.6 & 44.7 & 0.3 \\
\hline
\end{tabular}

a $t$ statistics for the mean difference between mother and father.

Significance level: ${ }^{\star \star \star} p<0.01$; ${ }^{\star \star} p<0.05 ;{ }^{*} p<0.1$.

Source: Author's summary based on TUS 2006. 


\section{References}

ABS (Australian Bureau of Statistics). 2008. Time Use Survey: User Guide, 2006. Available at: www.abs.gov.au/ausstats/abs@.nsf/mf/4150.0

Acock, Alan C. and David H. Demo. 1994. Family diversity and wellbeing. Thousand Oaks, CA: Sage.

Allard, Mary D. and Marianne Janes. 2008. 'Time use of working parents: a visual essay'. Monthly Labor Review June: 3-14.

Baxter, Janeen. 2002. 'Patterns of change and stability in the gender division of household labour in Australia, 1986-1997'. Journal of Sociology 38(4): 399-424. doi.org/10.1177/144078302128756750

Bryant, W. Keith and Cathleen D. Zick. 1996. 'An Examination of ParentChild Shared Time'. Journal of Marriage and Family 58(1): 227-237. doi.org/10.2307/353391

Casper, Lynne M. and Suzanne M. Bianchi. 2001. Continuity and change in the American family. Sage Publications.

Charlesworth, Sara, Lyndall Strazdins, Léan O’Brien and Sharryn Sims. 2011. 'Parents' jobs in Australia: Work hours polarisation and the consequences for job quality and gender equality'. Australian Journal of Labour Economics 14(1): 35.

Connelly, Rachel and Jean Kimmel. 2009. 'Spousal influences on parents' non-market time choices'. Review of Economics of the Household 7: 361-394. doi.org/10.1007/s11150-009-9060-y

Cooklin, Amanda, Huong Dinh, Lyndall Strazdins, Elizabeth Westrupp, Liana Leach and Jan Nicholson. 2016. 'Change and stability in workfamily conflict and mothers' and fathers' mental health: Longitudinal evidence from an Australian cohort'. Social Science and Medicine 155: 24-34. doi.org/10.1016/j.socscimed.2016.02.036

Craig, Lyn. 2007. 'How employed mothers in Australia find time for both market work and child care'. Journal of Family and Economic Issues 28(1): 69-87. doi.org/10.1007/s10834-006-9047-2 
Craig, Lyn and Michael Bittman. 2005. 'The effect of children on adults' time-use: analysis of the incremental time costs of children in Australia'. SPRC Discussion Paper. Sydney: Social Policy Research Centre.

Craig, Lyn, Abigail Powell and Ciara Smyth. 2014. 'Towards intensive parenting? Changes in the composition and determinants of mothers' and fathers' time with children 1992-2006'. The British Journal of Sociology 65(3): 555-579. doi.org/10.1111/1468-4446.12035

Craig, Lyn and Pooja Sawrikar. 2009. 'Work and Family: How Does the (Gender) Balance Change as Children Grow?' Gender, Work and Organization 16(6): 684-709. doi.org/10.1111/j.14680432.2009.00481.x

Del Boca, Daniela, Christopher Flinn and Matthew Wiswall. 2014. 'Household Choices and Child Development'. The Review of Economic Studies 81(1): 137-185. doi.org/10.1093/restud/rdt026

Dinh, Huong and Maria Racionero. 2016. Parents' primary and secondary child care time adjustment to market time: Evidence from Australian mothers and fathers. ANU Centre for Economic Policy Research Discussion Paper No. 695, Canberra.

Furedi, Frank. 2001. Paranoid parenting: Abandon your anxieties and be a good parent. London: Allen Lane.

Gutiérrez-Domènech, M. 2010. 'Parental employment and time with children in Spain'. Review of Economics of the Household 8(3): 371391. doi.org/10.1007/s11150-010-9096-z

Hallberg, Daniel and Anders Klevmarken. 2003. 'Time for children: A study of parent's time allocation'. Journal of Population Economics 16(2): 205-226. doi.org/10.1007/s001480200133

Kalenkoski, Charlene and Gigi Foster. 2008. 'The quality of time spent with children in Australian households'. Review of Economics of the Household 6(3): 243-266. doi.org/10.1007/s11150-008-9036-3

Kaufman, Gayle and Peter Uhlenberg. 2000. 'The influence of parenthood on the work effort of married men and women'. Social Forces 78(3): 931-947. doi.org/10.2307/3005936 
Kimmel, Jean and Rachel Connelly, 2007. 'Mothers' time choices caregiving, leisure, home production, and paid work'. Journal of Human Resources 42(3): 643-681. doi.org/10.3368/jhr.XLII.3.643

Nadesan, Majia. 2002. 'Engineering the entrepreneurial infant: Brain science, infant development toys, and governmentality'. Cultural Studies 16(3): 401-432. doi.org/10.1080/09502380210128315

Nock, Steven and Paul Kingston. 1988. 'Time With Children: The Impact of Couples' Work-Time Commitments'. Social Forces 67(1): 59-85. doi.org/10.2307/2579100

Quirke, L. 2006. “'Keeping Young Minds Sharp”: Children's Cognitive Stimulation and the Rise of Parenting Magazines, 19592003'. Canadian Review of Sociology/Revue canadienne de sociologie 43(4): 387-406.

Sayer, Liane. 2005. 'Gender, time and inequality: Trends in women's and men's paid work, unpaid work and free time'. Social Forces 84(1): 285-303. doi.org/10.1353/sof.2005.0126

Shaw, Daniel S. and Richard Q. Bell. 1993. 'Developmental theories of parental contributors to antisocial behavior'. Journal of Abnormal Child Psychology 21(5): 493-518. doi.org/10.1007/BF00916316

Wall, Glenda. 2010. 'Mothers' experiences with intensive parenting and brain development discourse'. Women's Studies International Forum 33(3): 253-263. doi.org/10.1016/j.wsif.2010.02.019

Zick, Cathleen D. and Bryant, W. Keith. 1996. 'A New Look at Parents' Time Spent in Child Care: Primary and Secondary Time Use'. Social Science Research 25(3): 260-280. doi.org/10.1006/ssre.1996.0012 
This text is taken from Tax, Social Policy and Gender: Rethinking equality and efficiency, edited by Miranda Stewart, published 2017 by ANU Press, The Australian National University, Canberra, Australia. 